Article

\title{
Ink-Jet Printing of Gluconobacter oxydans: Micropatterned Coatings As High Surface-to-Volume Ratio Bio-Reactive Coatings
}

Marcello Fidaleo $^{1, *}$, Nadia Bortone ${ }^{1}$, Mark Schulte ${ }^{2}$ and Michael C. Flickinger ${ }^{2,3}$

1 Department for Innovations in Biological, Agro-Food and Forest Systems, Via S. Camillo de Lellis, 01100 Viterbo, Italy; E-Mail: nadia2502@hotmail.it

2 Department of Chemical and Biomolecular Engineering, North Carolina State University, Engineering Building I, 911 Partners Way, Raleigh, NC 27695, USA;

E-Mails: mjschult@ncsu.edu (M.S.); mcflicki@ncsu.edu (M.C.F.)

3 Golden LEAF Biomanufacturing Training \& Education Center, 850 Oval Drive, Raleigh, NC 27606, USA

* Author to whom correspondence should be addressed; E-Mail: fidaleom@ unitus.it; Tel.: +39-0761-357-421; Fax: +39-0761-357-494.

Received: 17 September 2013; in revised form: 2 December 2013 / Accepted: 11 December 2013 / Published: 19 December 2013

\begin{abstract}
We formulated a latex ink for ink-jet deposition of viable Gram-negative bacterium Gluconobacter oxydans as a model adhesive, thin, highly bio-reactive microstructured microbial coating. Control of $G$. oxydans latex-based ink viscosity by dilution with water allowed ink-jet piezoelectric droplet deposition of $30 \times 30$ arrays of two or three droplets/dot microstructures on a polyester substrate. Profilometry analysis was used to study the resulting dry microstructures. Arrays of individual dots with base diameters of $\sim 233-241 \mu \mathrm{m}$ were obtained. Ring-shaped dots with dot edges higher than the center, 2.2 and $0.9 \mu \mathrm{m}$ respectively, were obtained when a one-to-four diluted ink was used. With a less diluted ink (one-to-two diluted), the microstructure became more uniform with an average height of $3.0 \mu \mathrm{m}$, but the ink-jet printability was more difficult. Reactivity of the ink-jet deposited microstructures following drying and rehydration was studied in a non-growth medium by oxidation of $50 \mathrm{~g} / \mathrm{L}$ D-sorbitol to L-sorbose, and a high dot volumetric reaction rate was measured $\left(\sim 435 \mathrm{~g} \cdot \mathrm{L}^{-1} \cdot \mathrm{h}^{-1}\right)$. These results indicate that latex ink microstructures generated by ink-jet printing may hold considerable potential for 3D fabrication of high surface-to-volume ratio biocoatings for use as microbial biosensors with the aim of coating microbes as reactive biosensors on electronic devices and circuit chips.
\end{abstract}


Keywords: biocatalytic latex inks and biocoatings; ink-jet printed biocoatings; whole-cell biosensors; immobilized G. oxydans; oxidation of D-sorbitol to L-sorbose

\section{Introduction}

Despite the great interest of engineers and biologists in developing direct writing ink-jet deposition methods to generate periodic arrays of three-dimensional nanoparticle microstructures and reactive biocoatings containing biomolecules and mammalian cells [1-5], few studies have appeared on how to formulate ink-jet inks for the deposition of a high concentration of viable microorganisms (bacteria, yeasts, fungi) ( $\sim 2$ to $\sim 10 \mu \mathrm{m}$ ) as thin adhesive coatings on surfaces or as bioreactive components of nano-structured or electronic devices [6-8]. Such "microbial inks" would be useful to precisely coat a high density of bioreporter microorganisms (microbes engineered to respond to chemicals in the environment by producing a detectable signal) directly onto the surface of electronic sensors, allowing the reduction of the size of biosensors to single integrated circuit chips. To this aim, these composite biomaterials must be adhesive, maintain nanoporosity and entrapped microbial viability as a dry coating and require minimal rehydration time for sensor activation. The coatings should be porous, deposited in thin layers $(<10 \mu \mathrm{m}$ thickness) and exhibit a high surface-to-volume ratio to reduce the diffusion distance of the molecules being detected, allowing the entrapped cells to be supplied with nutrients and oxygen to retain viability and reactivity.

Nanoporous, adhesive latex biocatalytic coatings offer the possibility of concentrating and entrapping viable microorganisms (such as bacteria, yeast or fungi) in very thin (five to $<75 \mu \mathrm{m}$ ), partially-coalesced polymer coatings [9-20]. Their thinness, engineered adhesion, nanoporous microstructure, mass-transfer properties [21-23], high-entrapped cell density and ability to be stored partially desiccated at ambient temperature differ significantly from the entrapment of viable microorganisms in crosslinked micro-porous carbohydrate gels, ceramic matrices, monoliths, soft synthetic polymer matrices (such as alginate or polyacrylamide) or behind membranes.

Latex biocatalytic coating formulations have begun to be evaluated as rapidly drying microbial inks for ink-jet deposition. Ink-jet processes can create patterned reactive surfaces to generate very high surface-to-volume ratio coatings [24-28] and biocoatings [6-8]. Ink-jet droplet deposition is an established large surface area coating and 3D printing technology that can be controlled to precisely deliver droplets containing engineered microbes instead of pigment particles onto a substrate and create patterns of nanoporous microstructures with defined height and large surface area without resulting in cell death during rapid ink deposition and drying. Latex biocoating formulations, originally used to coat $E$. coli onto polyester sheets in small surface area test patches of $>10 \mu \mathrm{m}$ thick using wire wound rod drawn down methods have been modified to reduce viscosity below $\sim 4 \mathrm{mPa} \cdot \mathrm{s}$ for piezoelectric droplet-on-demand layer-by-layer delivery of a very high density of viable microbes in $<5 \mu \mathrm{m}$ thick coatings onto polyester and other substrates. Model ink formulations were evaluated in different ink-jet printing devices with 25,50 or $64 \mu \mathrm{m}$ nozzle apertures [6-8,11]. Droplet sizes ranging from 0.1 to $0.5 \mathrm{~nL}$ were used to generate miniature square latex wells or $10 \times 10$ arrays of dot microstructures (1-5 droplets per dot, 100 or $250 \mathrm{~nL}$ total volume printed) containing latex and pmerR-lux E. coli, a model bioreactive microorganism engineered to respond to ionic mercury by 
bioluminescence. Recovery of viable E. coli (Colony Forming Units, CFU) by sonication of the coatings indicated $\sim 87 \%$ of the original cell viability prior to coating and drying. Luciferase luminescence was induced with $100 \mathrm{nM} \mathrm{Hg}^{+2}$, and arrays responded fully within $400 \mathrm{~min}$. Printed E. coli density was $(3.8-9.4) \times 10^{4} \mathrm{CFU}$ per dot (25 or $50 \mu \mathrm{m}$ tip, respectively) resulting in a printing density of $\sim 1.5-2$ E. coli $\mu \mathrm{m}^{-2}$ of the coating surface [11].

Recently, a latex coating has been developed consisting of a model metabolically active strictly aerobic Gram-negative bacterium, Gluconobacter oxydans, entrapped within a thin adhesive acrylate polymer matrix containing nanopores formed by partially coalesced latex particles and carbohydrates during controlled coat drying $(\sim 12-21 \mu \mathrm{m}$ thick). This highly reactive cell coat was sealed by a second thin nanoporous adhesive polymer layer topcoat ( 13-17 $\mu \mathrm{m}$ thick), and following rehydration, the coating selectively and quantitatively oxidized D-sorbitol to L-sorbose [29]. The kinetics of D-sorbitol oxidation with suspended cells and the catalytic parameters of the matrix (effective diffusion coefficients and active cell concentration) were estimated from independent experiments and used with a diffusion-reaction model to predict the effectiveness factor and the effective reaction rate as a function of cell coat thickness, topcoat thickness and dissolved oxygen concentration in the liquid medium. Highly effective L-sorbose production rates $\left(>84 \mathrm{~g} \cdot \mathrm{L}^{-1} \cdot \mathrm{h}^{-1}\right)$ were predicted by the model and observed experimentally. Direct counting of viable $G$. oxydans from patches disrupted by mild sonication showed a considerable loss of cell viability (50\%) during drying of the cell coat and a further reduction after the addition of the topcoat. In spite of this viability loss, which resulted in a viable cell concentration in the cell coat of top coated patches of $5.87 \times 10^{-2}$ to $9.65 \times 10^{-2}$ cells $_{\mu m^{-3}}$, the reactivity of the coating was much greater than any previously reported for this G. oxydans oxidation in immobilized systems. Recently, Fidaleo and Flickinger [30] performed a model-based investigation of the reactivity of a multi-phase microchannel bioreactor coated internally with the above coating for the high intensity oxidation of D-sorbitol to L-sorbose.

Whole cells of $G$. oxydans containing stereo-specific dehydrogenase enzymes have proven to be useful model systems for the development of bacterial biosensors for detecting alcohols, carbohydrates and polyols [31]. In fact, G. oxydans possesses a large number of dehydrogenases located in the cytoplasmic membrane that can quantitatively oxidize polyols to ketones, ethanol to acetic acid and sugars to acids [32]. Substrates, which have to diffuse through the outer membrane pores, are rapidly oxidized in one or two steps in the periplasmic space between the outer membrane and the cytoplasmic membrane, and these partially oxidized substrates accumulate in the extracellular space at high concentration and yield. The development of amperometric biosensors based on Gluconobacter or Acetobacter cells and on an oxygen electrode as the electro-chemical detector for the detection of lactate [33], ethanol [34], glycerol [33], biochemical oxygen demand (BOD) [35], D-xylose [36], D-fructose [34], a mixture of D-glucose and ethanol [37,38], sucrose (co-immobilization of S. cerevisiae) [39] and lactose (co-immobilization of Kluyveromyces marxianus) [39] has been reported in the literature. Recent advances in the field of "gluconosensors" have been reported [40]. The current research trend focuses on applying innovative designs, materials and methodologies with the aim of enhancing the functionality of this cell-based biosensor. In particular, as underlined by Tkáč et al. [41], only a limited number of immobilization techniques were used for the preparation of whole cell G. oxydans biosensors, including gel entrapment with crosslinking, containment behind membranes and adsorption on a filtration paper or a porous nitrocellulose filter. 
In this paper, we report the development of improved ink-jet coating methods for the generation of G. oxydans latex biocatalytic microstructures with very high reactivity following ink-jet deposition, coat drying and rehydration. This method will allow the fabrication of ultra-thin bio-coatings with extremely high reactivity to reduce the size of microbial biosensors to single integrated circuit chips and enable high speed manufacturing of bioelectronic devices.

\section{Materials and Methods}

\subsection{Gluconobacter oxydans Ink Preparation and Characterization}

\subsubsection{Cultivation of G. oxydans}

Gluconobacter oxydans ATCC 621 (American Type Culture Collection, Manassas, VA, USA) was grown on sorbitol yeast extract medium (SYE) containing $5 \mathrm{~g} \cdot \mathrm{L}^{-1}$ of yeast extract (Acros Organics, Geel, Belgium) and $50 \mathrm{~g} \cdot \mathrm{L}^{-1}$ of D-sorbitol (initial $\mathrm{pH}$ adjusted to 6.0 by $1 \mathrm{~mol} \cdot \mathrm{L}^{-1} \mathrm{HCl}$ ) and cultured in baffled Erlenmeyer flasks incubated at $30{ }^{\circ} \mathrm{C}$ and $250 \mathrm{rpm}$ in an orbital shaker. G. oxydans was maintained by weekly subculture on SYE medium plus $20 \mathrm{~g} \cdot \mathrm{L}^{-1}$ agar (Fisher Scientific, Pittsburgh, PA, USA).

\subsubsection{Ink Formulation and Rheology}

The ink formulation for immobilization of $G$. oxydans was prepared according to the following ratio [29]: $1.2 \mathrm{~g}$ of $G$. oxydans wet cell paste, $0.37 \mathrm{~mL}$ filter-sterilized sucrose solution $\left(0.58 \mathrm{~g} \mathrm{~mL}^{-1}\right)$, $0.15 \mathrm{~mL}$ autoclaved neat glycerol and $1 \mathrm{~mL}$ of latex emulsion. The latex binder emulsion, Rovace SF091 (Rohm and Haas, Spring House, PA, USA), a monodispersed copolymer vinyl acetate-co-acrylic latex emulsion (average particle size: $\sim 300 \mathrm{~nm}$; solids content: $54.9 \% \mathrm{w} / \mathrm{w}$; glass transition temperature: $\sim 10{ }^{\circ} \mathrm{C}$ ) adjusted to $\mathrm{pH} 6.0$ and formulated without biocide was used. After 16-20 h of cultivation, G. oxydans cells grown in SYE medium were harvested by centrifugation and the cell pellet washed twice with an autoclaved sorbitol phosphate buffer (SP) containing $50 \mathrm{~g} \cdot \mathrm{L}^{-1} \mathrm{D}$-sorbitol, $0.125 \mathrm{~g} \cdot \mathrm{L}^{-1} \mathrm{~K}_{2} \mathrm{HPO}_{4}$ and $0.35 \mathrm{~g} \cdot \mathrm{L}^{-1} \mathrm{NaH}_{2} \mathrm{PO}_{4}$ (pH adjusted to 6.0 with $\mathrm{HCl} 1 \mathrm{~mol} \cdot \mathrm{L}^{-1}$ ). Sterile sucrose and glycerol were added directly to the wet cell paste according to the abovementioned ratio and mixed gently with a sterile spatula for about $5 \mathrm{~min}$. The latex binder emulsion was then added and mixed gently for an additional 5 min. Ink-jet inks were prepared by diluting the abovementioned formulation with several amounts of filter-sterilized water for subsequent printing and used immediately after preparation.

Ink viscosity was measured by using a dynamic stress rheometer (Ares, Rheometric Scientific Inc., Piscataway, NJ, USA) equipped with plate-and-plate sensors (50 mm diameter, $0.5 \mathrm{~mm}$ gap) at $22{ }^{\circ} \mathrm{C}$.

\subsection{Ink-Jet Printing of G. oxydans Inks}

\subsubsection{Description of the Ink-Jet Plotter}

A four print head robotic plotter (model NP1.2 Gesellschaft für Silizium-Mikrosysteme, GeSIM $\mathrm{mbH}$, Großerkmannsdorf, Germany) was used for ink-jet deposition of dot arrays of latex inks containing G. oxydans. The plotter was located in an acrylic chamber with humidity and temperature 
monitoring. An interchangeable piezoelectric nanotip with an aperture diameter equal to $50 \mu \mathrm{m}$ ( $90 \mu \mathrm{m}$ diameter droplet) was used. Cameras monitored drop formation and impact on the substrate attached to the $260 \mathrm{~mm} \times 270 \mathrm{~mm} \mathrm{X}-\mathrm{Y}$ workspace. Ink and piezo tip cleaning fluids were aspirated from wells of a 384-well microtiter plate mounted on the workspace. Latex emulsion drying rate in the microtiter plate wells was not significant during the time needed for dot array printing. An automated tip cleaning protocol was developed using a tip flushing, surface cleaning and blotting workstation mounted adjacent to the workspace. Aspiration volume, droplet deposition density and the pitch (spacing) of dot arrays were programmed using NP12 software (GeSIM mbH, Großerkmannsdorf, Germany). Arrays of $30 \times 30$ latex dots of 2 to 3 droplets per dot and $0.3 \mathrm{~mm}$ pitch were deposited onto a $124 \mu \mathrm{m}$-thick polyester sheet cleaned with water and ethanol at $70 \% v / v$. Piezo tips were cleaned by printing each dot array with $70 \%$ isopropanol in filtered water, flushed with filtered water to remove isopropanol and blotted.

\subsubsection{Profilometry Measurements and Estimation of Microstructure Dimensions}

The 3D surface profile of printed dot arrays (microstructures) was visualized using a contact profiler (Model Talyscan 150, Taylor Hobson Precision, Leicester, England). ImageJ software (National Institutes of Health, Bethesda, MD, USA) was used to process images obtained by Talymap Platinum software (Taylor Hobson Precision, Leicester, England) from data collected by the profiler. The geometry of the dots was approximated with either a conical frustum (structures generated with the 1-to-2 diluted ink) or as the solid that is left by intersecting two parallel conical frusta on the same vertical axis (structures generated with the 1-to-4 diluted ink). The dimensions of three dots chosen randomly from the $2.5 \mathrm{~mm} \times 2.5 \mathrm{~mm}$ images collected for each condition tested were measured and their mean and standard deviation reported.

\subsection{Measurement of Microstructure Reactivity}

After drying for $1 \mathrm{~h}$ under an acrylic chamber at $20{ }^{\circ} \mathrm{C}$ and $60 \%$ relative humidity, as monitored by a calibrated digital temperature and relative humidity sensor (model TM125, Dickson, Addison, IL), each $30 \times 30$ dot array on polyester sheet was punched out with a $10-\mathrm{mm}$ diameter punch and aseptically placed in a sterile $60 \mathrm{~mm} \times 15 \mathrm{~mm}$ petri dish containing $5 \mathrm{~mL}$ of non-growth $\mathrm{SP}$ buffer and incubated at $30^{\circ} \mathrm{C}$ and $90 \mathrm{rpm}$ for $1 \mathrm{~h}$ for rehydration and washing. Each patch was then removed from the petri dish and placed upside down (with the dot arrays facing the bottom of the well) into the wells of a 24-well plate (Costar ${ }^{\circledR} 3524$, Cambridge, MA, USA) previously filled with $0.5 \mathrm{~mL}$ of SP buffer. The 24-well plate was covered with a Breathe-Easy gas permeable sealing membrane for microtiter plates (Diversified Biotech, Boston, MA, USA) and incubated on an orbital shaker in an incubator with humidification. Twenty-microliter liquid samples were removed periodically to measure L-sorbose accumulation.

L-sorbose was determined using a Dionex DX500 HPLC system equipped with a CarboPac MA1 anion exchange column and its guard column (Dionex Corporation, Sunnyvale, CA, USA) and the ED40 electrochemical detector (Dionex Corporation, Sunnyvale, CA, USA). Samples and standards were diluted 1:10 with deionized water and further diluted 1:10 in an aqueous solution containing 20 $\mathrm{mg} \cdot \mathrm{L}^{-1} \mathrm{D}$-glucose (internal standard). Degassed, deionized water and $0.6 \mathrm{~mol} \cdot \mathrm{L}^{-1} \mathrm{NaOH}$ (in degassed, 
deionized water) in the volumetric ratio 1:3 were used as the mobile phase at a flow rate of $0.5 \mathrm{~mL} \cdot \mathrm{min}^{-1}$. The ratio of the peak areas of L-sorbose and D-glucose was converted to L-sorbose concentration from a calibration curve. The linearity range and the detection limit were $0-100 \mathrm{mg} \cdot \mathrm{L}^{-1}$ and $2.2 \mathrm{mg} \cdot \mathrm{L}^{-1}$, respectively. Elution times for D-sorbitol, D-glucose and L-sorbose were, respectively, $12.6 \mathrm{~min}, 16.6 \mathrm{~min}$ and $20 \mathrm{~min}$, respectively.

\section{Results and Discussion}

\subsection{Viscosity of G. oxydans Latex Emulsions}

Droplet formation in ink-jet printing is influenced by the physical properties of the ink, in particular dynamic (or shear) viscosity $(\eta)$, density $(\rho)$ and surface tension $(\gamma)$. Fromm [42] provided a dimensional analysis of the mechanics of drop formation in drop-on-demand systems by grouping the abovementioned physical properties of the ink into a $Z$ number:

$$
Z=(d \rho \gamma)^{1 / 2} / \eta
$$

where $d$ is the diameter of the nozzle aperture. According to Fromm, drop formation in drop-on-demand systems was only possible for $Z>2$. While slightly different $Z$ ranges for printability have been suggested by other authors [43], Equation (1) shows that any reduction in ink viscosity results in increasing $Z$ numbers and, thus, in better printability.

Ink-jet printing with the GeSIM nano-plotter (according to the manufacturer's specifications) requires inks with dynamic viscosity of less than $5 \mathrm{mPa} \cdot \mathrm{s}$. The viscosity of the original formulation of the G. oxydans latex emulsion, as measured by performing strain sweep tests, was found to be shear rate-dependent and varied from about 52 to $16 \mathrm{mPa} \cdot \mathrm{s}$ as the shear rate increased from 1 to $1000 \mathrm{~s} \mathrm{~s}^{-1}$. Thus, while for the preparation of coatings by the Mayer rod drawdown coating method [29] the viscosity of the emulsion is appropriate, for ink-jet printing with the GeSIM plotter, it was too high. In order to reduce ink viscosity, latex inks were prepared by diluting the original $G$. oxydans latex emulsion with deionized water, in agreement with Flickinger et al. [6-8], who diluted several E. coli latex emulsions with water in order to obtain ink viscosity in the range of 1.5 to $3 \mathrm{mPa} \cdot \mathrm{s}$.

\subsection{Study of Ink-Jet Printed G. oxydans Micropatterned Coatings}

\subsubsection{Profilometry of Deposited Microstructures}

Profilometry was used to analyze the shape of ink-jet printed arrays of dry dot microstructures. The original ink formulation was diluted by adding one or three volumes of water to one volume of original ink dispersion to reduce its solids content. The addition of water reduces the viscosity of the solvent (made up of water, glycerol and sucrose) and decreases the concentration of latex particles and cells, improving printability. However, dispersed suspensions at low concentrations can undergo the well-known "coffee ring effect" [44], which leads to a nonuniform deposition of particles. This well-known phenomenon has been observed with several systems of a solid dispersed in a drying drop and occurs for a wide range of surfaces, solvents and solutes [45]. Deegan et al. [45] described the phenomenon as being due to a greater evaporation rate at a droplet's pinned contact line than at its 
center. This causes material to be transported to the boundary by an outward flow of solvent from the center, since the contact line cannot retract.

The use of a one-to-four diluted ink resulted in ring-shaped dots with depressions (craters) at the center of the dots (Figure 1A,B), the typical morphology corresponding to the abovementioned "coffee ring effect". This morphology was observed also by Flickinger et al. [6-8] with $10 \times 10$ arrays of latex dot microstructures (1-5 droplets per dot) containing pmerR-lux E. coli.

Figure 1. Profilometer image of G. oxydans $30 \times 30$ latex dot arrays ink-jet printed on polyester sheet, two droplets per dot, one-to-four diluted ink $(\mathbf{A}, \mathbf{B})$ or three droplets per dot, one-to-two diluted ink $(\mathbf{C}, \mathbf{D})$. 3D profile of a $2.5 \times 2.5 \mathrm{~mm}^{2}$ scanned area of a dot array $(\mathbf{A}, \mathbf{C})$; profile of the section line corresponding approximately to the centers of dots belonging to a row or column $(\mathbf{B}, \mathbf{D})$.

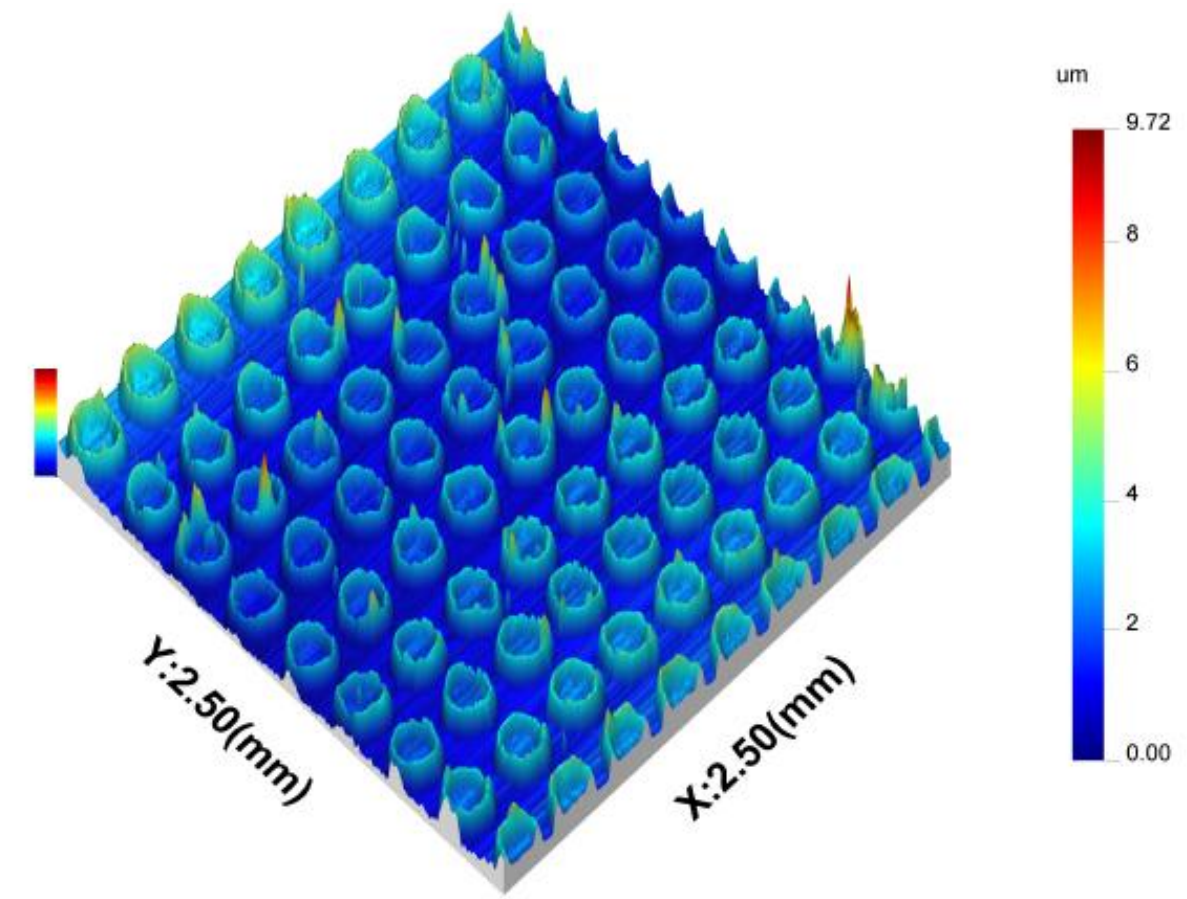

(A)

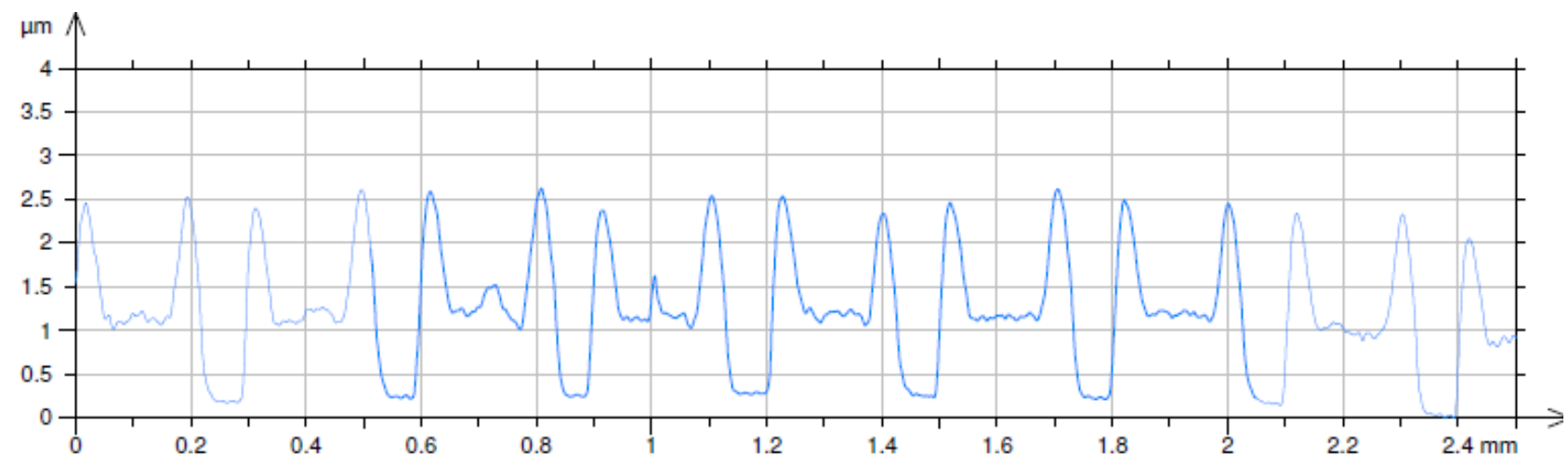

(B) 


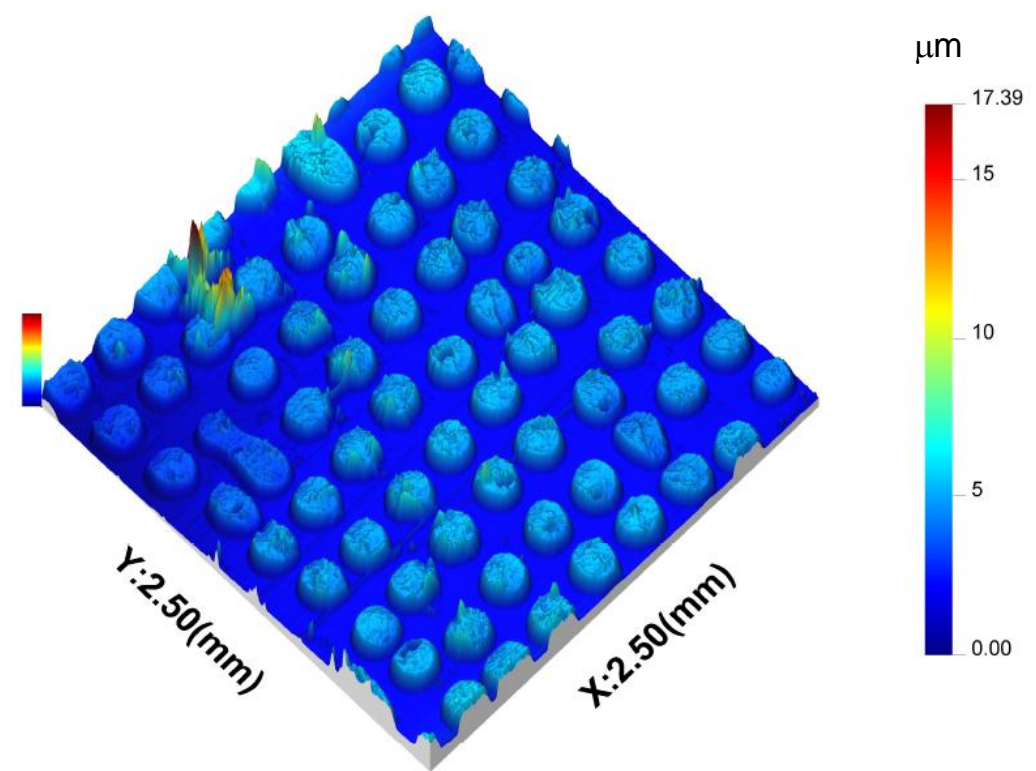

(C)

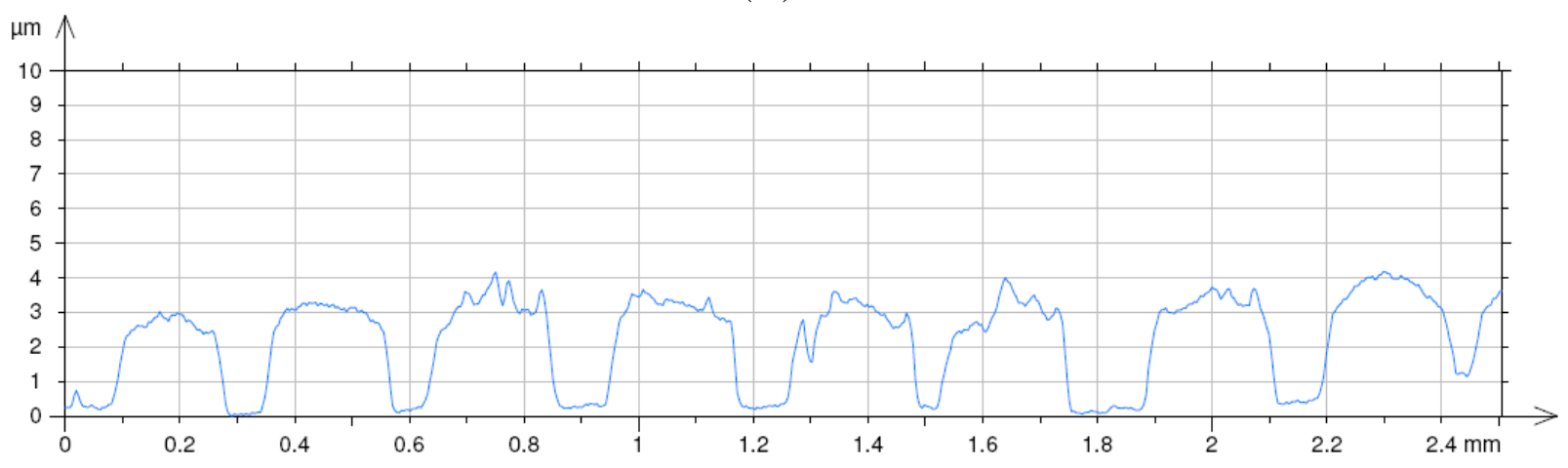

(D)

With a one-to-two diluted ink formulation, the dots appeared more uniform, and the formation of craters was completely avoided (Figure 1C,D). This morphology is desired for biosensors to deposit the biological element uniformly as a coating onto the active biosensor surface. On the other hand, one can think of a scenario where the coffee ring phenomenon could be used to produce microstructures that are finer than the droplets used to produce them. It is worth noting that, while the higher viscosity and solids content of the one-to-two diluted ink resulted in more uniform dot morphologies, it also made the printing process more difficult and more prone to nano-plotter head obstruction.

In order to estimate the dimensions of the microstructures, each dot was approximated with a conical frustum (Figure 2A) or with a solid obtained by intersecting two conical frustums (Figure 2B). The geometric properties determined and averaged over three dots are summarized in Table 1.

In particular, the mean G. oxydans dot thickness in the interior part (crater) of dots obtained with the one-to-four diluted ink was $0.89 \pm 0.04 \mu \mathrm{m}$ with a maximum edge thickness of $\sim 2.23 \pm 0.07 \mu \mathrm{m}$, while the mean dot thickness of dots obtained with the one-to-two diluted ink was of $3.0 \pm 0.2 \mu \mathrm{m}$. 
Figure 2. Schematic representation of the shape of SF091 latex dot containing G. oxydans ink-jet printed on polyester sheet: two droplets per dot, one-to-four diluted ink (A); three droplets per dot, one-to-two diluted ink (B). Geometrical parameters: $a$, base diameter; $b$, top diameter; $c$, well base diameter; $h_{1}$, height of well; $h_{2}$, height of conical frustum.
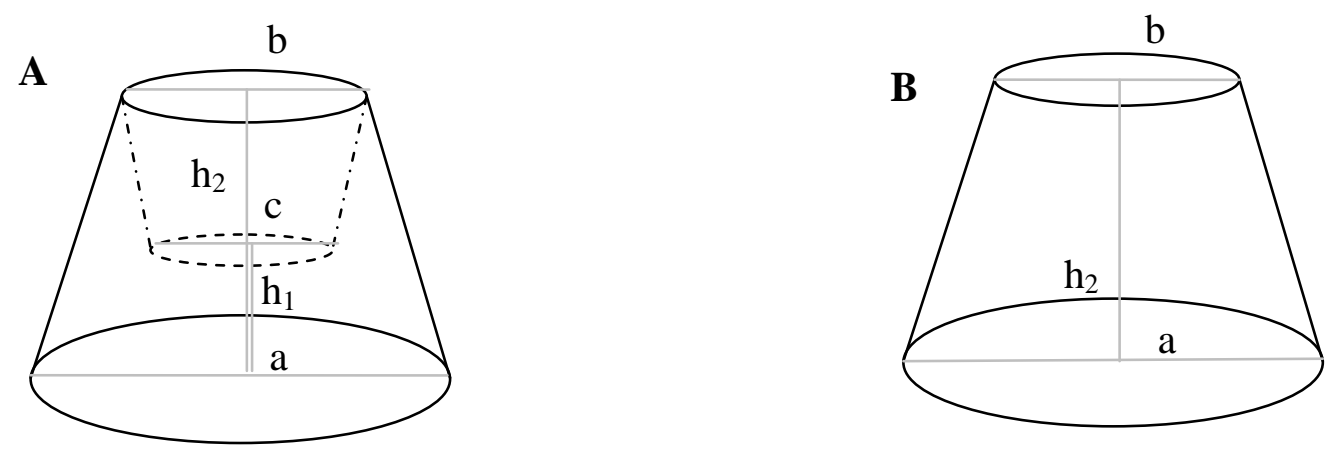

Table 1. Geometric and catalytic properties of a single dot of a $30 \times 30$ dot array of G. oxydans latex ink-jet microstructure printed on a polyester sheet. Geometric parameters were determined by ImageJ software starting from images obtained by Talymap Platinum software (Taylor Hobson Precision, Leicester, England). Mean and standard deviation of measurements from three dots are reported.

\begin{tabular}{|c|c|c|c|}
\hline Parameter & \multicolumn{2}{|c|}{ Numerical value } & Unit \\
\hline Emulsion dilution factor & 4 & 2 & - \\
\hline Number of droplets per dot & 2 & 3 & - \\
\hline Base diameter $(a)$ & $241 \pm 9$ & $233 \pm 4$ & $\mu \mathrm{m}$ \\
\hline Top diameter $(b)$ & $174 \pm 7$ & $176 \pm 5$ & - \\
\hline Well diameter $(c)$ & $114 \pm 10$ & - & - \\
\hline Volume $(V)$ & $(54 \pm 5) \times 10^{3}$ & $\begin{array}{c}(100 \pm 4) \times \\
10^{3}\end{array}$ & $\mu \mathrm{m}^{3}$ \\
\hline Lateral surface area $(S)^{1}$ & $(46 \pm 4) \times 10^{3}$ & $(43 \pm 2) \times 10^{3}$ & $\mu \mathrm{m}^{2}$ \\
\hline Height $\left(h_{1}, h_{2}\right)^{2}$ & $\begin{array}{c}0.89 \pm 0.04,2.2 \pm 0.1 \\
0.38\end{array}$ & $\begin{array}{c}-, 3.0 \pm 0.2 \\
0.62\end{array}$ & $\begin{array}{c}\mu \mathrm{m} \\
\text { cells } \cdot \mu \mathrm{m}^{-3}\end{array}$ \\
\hline Cell concentration & $\begin{array}{c}0.45 \\
20.6 \times 10^{3}\end{array}$ & $\begin{array}{c}1.45 \\
61.8 \times 10^{3}\end{array}$ & $\begin{array}{l}\text { cells } \cdot \mu \mathrm{m}^{-2} \\
\text { cells } \cdot(\mathrm{dot})^{-1}\end{array}$ \\
\hline L-sorbose reaction rate ${ }^{3}$ & not determined & 435 & $\mathrm{~g} \cdot \mathrm{L}^{-1} \cdot \mathrm{h}^{-1}$ \\
\hline- & not determined & 1.02 & $\mathrm{~g} \cdot \mathrm{m}^{-2} \cdot \mathrm{h}^{-1}$ \\
\hline
\end{tabular}

${ }^{1}$ Calculated as the area of lateral and top surface; ${ }^{2}$ determined as the height of the crater and crest of the one-to-four diluted ink or the height of the conical frustum for the one-to-two diluted ink. ${ }^{3}$ reaction rates are referred to as either the dot volume or the dot base surface area.

\subsubsection{Reactivity}

When a $G$. oxydans ink-jet printed dot is placed in contact with an oxygen-saturated solution containing D-sorbitol, the sugar diffuses through the nanoporous microstructure and is converted quantitatively by the membrane-bound sorbitol dehydrogenase located on the periplasmic side of the cytoplasmic membrane of the G. oxydans cells [29] into D-sorbitol without cell growth, according to the following reaction: 


$$
\text { D-sorbitol }+1 / 2 \mathrm{O}_{2} \rightarrow \text { L-sorbose }+\mathrm{H}_{2} \mathrm{O}
$$

The oxidation of D-sorbitol to L-sorbose by washed, $30 \times 30$ dot arrays of $G$. oxydans one-to-two diluted latex ink ink-jet printed on polyester was investigated in non-growth SP buffer for $83.5 \mathrm{~h}$. After $64 \mathrm{~h}$ of incubation, the patches were removed from the wells of the plate in order to quantify the contribution to the bioconversion of any G. oxydans cells leaked from the dots into the liquid medium.

Table 1 reports the catalytic properties of the dot array. By plotting L-sorbose concentration vs. time (Figure 3), it was possible to estimate L-sorbose volumetric reaction rate (referred to as the liquid volume in the well of the microplate) from the slope of the least squares straight line as equal to $0.135 \pm 0.001 \mathrm{~g} \cdot \mathrm{L}^{-1} \cdot \mathrm{h}^{-1}$ for an array of dots obtained by depositing three drops per dot. After removing the patches from the non-growth liquid medium, the L-sorbose reaction rate dropped to $0.037 \mathrm{~g} \cdot \mathrm{L}^{-1} \cdot \mathrm{h}^{-1}$, indicating that $G$. oxydans cells released from the microstructures into the liquid medium were contributing only a small fraction of the observed overall L-sorbose production. Previous coating studies using the same latex formulation have shown that without a porous polymer top coat, a small amount of G. oxydans cells can be released from the surface of the ink dots. It is not likely that cells are released from the inner part of the structure, where the nanoporous interstices between the cells and the partially coalesced polymer particles have dimensions less than G. oxydans cells [29]. Images of the top surface of rehydrated latex coatings of both E. coli and G. oxydans show that coatings maintain their polymer backbone after rehydration, but oblong holes appear in the polymer matrix at places from where the bacterial cells have left during rehydration [22,29]. The dimensions of G. oxydans in suspension and entrapped in latex coatings is $\langle 1 \mu \mathrm{m}$ by $\sim 2-4 \mu \mathrm{m}$, and therefore, the estimated average printed coating thickness over the entire dot is about one or three cells-thick for the two droplets or the three droplets dot microstructures, respectively. Fidaleo et al. [29] studied cell release from G. oxydans coatings and were able to control the loss of cells from the coating into non-growth media by using a second nanoporous layer of sealant latex coating on top of the $G$. oxydans cell coat. This approach could be used easily with ink-jet printed G. oxydans dots by covering them with a second, thin, nanoporous sealant layer without cells, ink-jet printed on top of the dots. By subtracting the reaction rate due to released cells from the reaction rate due to both released cells and cells embedded in the ink and taking into account liquid volume decrease due to both evaporation and sample withdrawal (the final liquid volume in each microplate well was $0.3 \mathrm{~mL}$ compared to $0.5 \mathrm{~mL}$ of initial volume), it was possible to estimate an approximated net L-sorbose production rate per dot equal to $43.5 \times 10^{-9} \mathrm{~g} \cdot \mathrm{h}^{-1} \cdot \mathrm{dot}^{-1}$. Since the volume of a single dot, as estimated by ImageJ software from Figure $1 \mathrm{C}$, was equal to $(100 \pm 4) \times 10^{3} \mu \mathrm{m}^{3}$, the L-sorbose production rate referred to as the dot volume was equal to $435 \mathrm{~g} \cdot \mathrm{L}^{-1} \cdot \mathrm{h}^{-1}$. The L-sorbose reaction rate determined in this work was higher than the values of 84 or $102 \mathrm{~g} \mathrm{~L}$-sorbose $\mathrm{L}^{-1} \cdot \mathrm{h}^{-1}$ measured with 12.7-mm latex patches of $G$. oxydans two-layer coatings made up of a $21.2-\mu \mathrm{m}$ cell coat and $13.1-\mu \mathrm{m}$ or $12.2-\mu \mathrm{m}$ nanoporous sealant topcoat, respectively [29]. Fidaleo et al. [29] developed a diffusion reaction model for the abovementioned two-layer coating showing that the decrease of topcoat layer determines a dramatic increase of the coating reactivity due to both the reduction of internal mass transfer limitations and the increase of the viability of cells in the cell coat. Thus, the higher reactivity measured in this work may be explained by the thinness of the dot microstructure and the absence of a nanoporous polymer top layer. The external mass transfer limitations, not considered by the model, which depend on the reaction system used, may also play a role in limiting the experimentally 
observed reaction rates in comparison to model predictions. Thus, the high reactivity measured in this work is consistent with Fidaleo et al.'s predictions [29] based on a diffusion reaction model for G. oxydans two-layer coatings. As discussed previously [29], immobilization of G. oxydans in latex coatings is characterized by very high reactivity compared to other viable cell immobilization techniques. For instance, recently, Wang et al. [46] using $25 \mathrm{~g} \cdot \mathrm{L}^{-1}$ of alginate beads (3-mm diameter particles) in a 1 -L fermenter loaded with $500 \mathrm{~mL}$ of aqueous medium containing $150 \mathrm{~g} \cdot \mathrm{L}^{-1}$ of D-sorbitol obtained a L-sorbose production of $\sim 100 \mathrm{~g} \cdot \mathrm{L}^{-1}$ after $48 \mathrm{~h}$ of bioconversion, corresponding to a volumetric reaction rate of the alginate beads of about $100 \mathrm{~g} \cdot \mathrm{L}^{-1} \cdot \mathrm{h}^{-1}$ (assuming a density of the wet alginate beads equal to $1136 \mathrm{~g} \cdot \mathrm{L}^{-1}$ ); however, this rate is more than four-fold lower than the value reported in the present study utilizing very thin biocoatings deposited using ink-jet droplet deposition. It is worth noting that the surprisingly high reactivity estimated from Wang et al.'s data may be inflated by the unreported contribution of cells released from the mechanically unstable hydrogel beads: these released cells likely proliferated in the growth medium and contribute to the observed reaction rate.

Figure 3. Oxidation of D-sorbitol to L-sorbose with G. oxydans ink-jet printed $30 \times 30$ dot arrays, three drops per dot, one-to-two diluted ink, in $0.5 \mathrm{~mL} \mathrm{SP}$ buffer at $30{ }^{\circ} \mathrm{C}$ and $90 \mathrm{rpm}$ : concentration of L-sorbose $\left(C_{\mathrm{P}}\right)$ as a function of time $(t)$. After $64 \mathrm{~h}$ of incubation, the ink-jet printed polyester patches were removed from the 24 -well plate. Data refer to the mean and standard deviation of three replicated experiments.

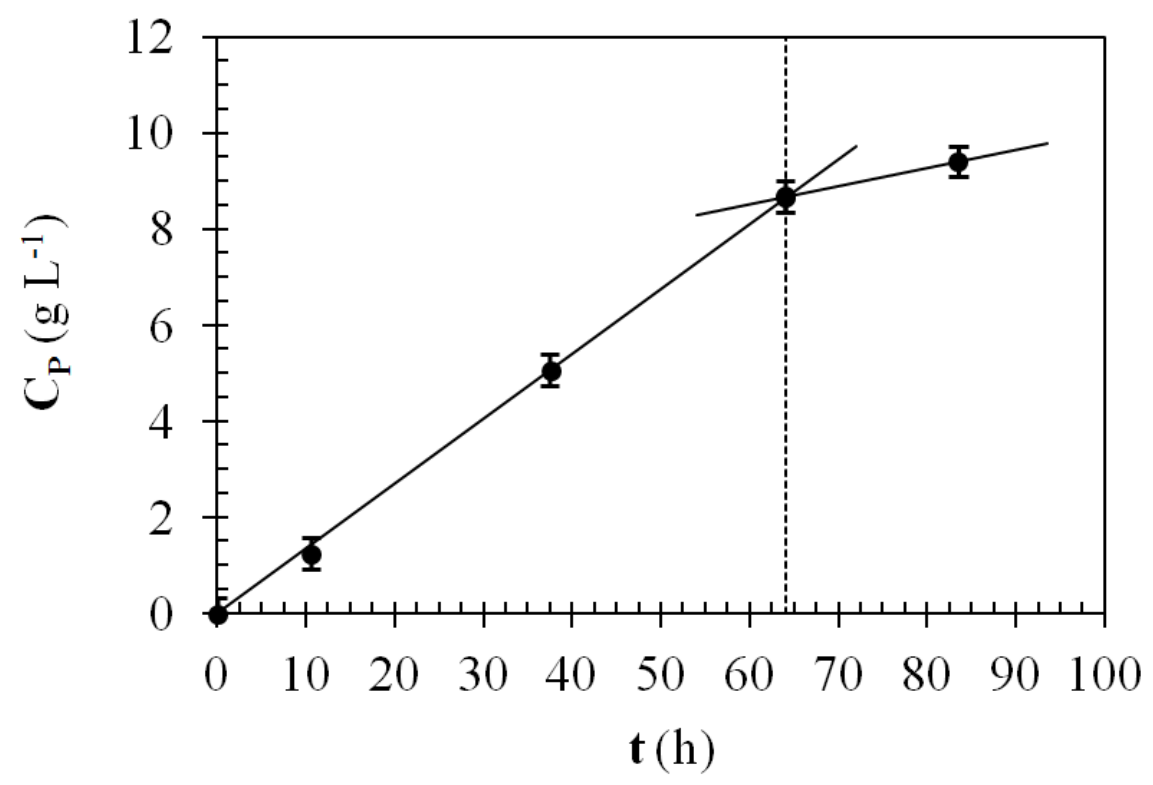

Finally, Table 1 reports also the L-sorbose reaction rate and G. oxydans concentration based on per unit polyester surface area, a more useful base when dealing with surface reactions and coatings.

\subsubsection{Coating Volumetric and Superficial Cell Concentration}

The volumetric concentration of cells in the dry dot microstructures depends on the composition of the ink formulation, independently of the dilution carried out to lower the ink viscosity. On the contrary, the superficial cell concentration, expressed as the ratio between the total number of cells 
embedded in the coating and the substrate surface area occupied by the coating, depends on the structure of the dry coating, in particular, its thickness. The undiluted ink contained $\sim 1.08 \times 10^{8}$ cells $\mu \mathrm{L}^{-1}$, and the drying process leads to a decrease of its volume by four times [29]. Thus, the volumetric cell concentration of the dried ink was expected to be about 0.43 cells $\mu \mathrm{m}^{-3}$. Cell concentration in the dot before any possible cell leakage, estimated by assuming that the $50-\mu \mathrm{m}$ diameter head ejected $90-\mu \mathrm{m}$ diameter ink droplets [6,8], is reported in Table 1 for both printed microstructures. The cell concentration in the microstructure generated by ejecting two droplets of the one-to-four diluted ink or three droplets of the one-to-two diluted ink were estimated as being equal to 0.38 cells $\mu^{-3}$ or 0.62 cells $\mu \mathrm{m}^{-3}$, respectively, thus consistent with the predicted value of 0.43 cells $\mu \mathrm{m}^{-3}$.

\subsubsection{Generation of Increased Surface Area Biocoatings Using Ink Jet Microstructure Pillar Arrays}

Previous work on latex biocatalytic coatings has shown that cell activity decreases along the depth of a coating [47,48]. Adding more cell layers to increase reactivity will actually diminish the specific reaction rate (mass product $/$ mass $_{\text {cells }} /$ time) as diffusion limitations dominate. In order to increase reactivity by increasing catalyst concentration (cells), more available coating surface area must be created. This is a unique advantage of the inkjet method proposed. Through additive construction of 3D microstructures, high surface-to-volume ratio structures can be created. Furthermore, by using an additive construction method instead of a subtractive one, one can avoid feature collapse as structures become smaller, as no rinse step is needed [49]. Additionally, to coat a highly patterned surface would result in voids being filled and a significant reduction in surface area. However, high surface area can be fashioned and maintained by creating a patterned, reactive surface initially out of the biocatalytic material using ink-jet deposition.

In order to enhance the specific surface area, the aspect ratio of the ink-jet printed 3D microstructures (ratio of height to diameter of dot-like structures) must be maximized. Piezoelectric ink-jet controlled droplet deposition of gold nanoparticles has achieved aspect ratios >50 [28]. However, for polymers, PZT (lead zirconium titanate) printing with a poly(vinyl butyral) binder has achieved an aspect ratio of $\sim 5$, but needed $>1000$ layers [24]. Higher aspect ratio structures will require improved ink formulations, as well as precise printing systems, as multiple layers deposited at the exact same point on the substrate will be required.

The preliminary ink-jet printed microstructures obtained in this work showed an aspect ratio of $<0.02$ and are essentially flat dots (disks). Further optimization of the latex coating emulsion and ink-jet printing system (not the focus of this work) will allow for the generation of significantly more surface area and an increased number of reactive cells per coating microstructure. Improvements in surface area as a function of aspect ratio can be seen in Table 2, where ink-jet coatings are compared with a monolayer of $G$. oxydans cells, as could be obtained by convective-sedimentation assembly [50]. Increased available surface area can come through improving ink-jet methods (ink formulation, droplet control). This improved surface area will allow for better diffusion of reactants/products to/from the biocatalyst. Additionally, by increasing the microstructure aspect ratio to what has been reported in the literature, one can predict that the cell concentration will increase by more than three orders of magnitude over a monolayer of $G$. oxydans cells. The reactivity may not scale linearly with cell number, but in comparison to a monolayer, the reactivity should be markedly higher. 
Recent work has shown ink-jet printing to be able to create very complicated 3D structures that may be more structurally stable than tall pillars [28]. Improving the catalytic surface area has been reported to improve chemical processes [51] and can do the same for whole cell biocatalysis using this ink-jet coating method.

Table 2. Comparison of the theoretical surface area $(S)$ and total number of $G$. oxydans cells $(N)$ from a monolayer of $G$. oxydans cells [50] and an inkjet printed dot array of $250-\mu \mathrm{m}$ diameter cylindrical dots of various aspect ratios (height/diameter). Dots are spaced $50 \mu \mathrm{m}$, and the surface of the substrate is $1 \mathrm{~m}^{2}$. Calculations were carried out assuming a $G$. oxydans cell size of $0.8 \mu \mathrm{m} \times 4 \mu \mathrm{m}$ and using a cell concentration in the coating of 0.62 cells $/ \mu \mathrm{m}^{3}$ (Table 1 ).

\begin{tabular}{cccc}
\hline Coating type & Aspect ratio & $\mathbf{S ~}\left(\mathbf{m}^{2}\right)$ & $\boldsymbol{N}$ \\
\hline Monolayer of cells & - & 1 & $3.1 \times 10^{11}$ \\
Coating (this work) & 0.013 & 0.57 & $1.1 \times 10^{12}$ \\
Coating & 1 & 2.7 & $8.4 \times 10^{13}$ \\
Coating & 3 & 7.1 & $2.5 \times 10^{14}$ \\
Coating & 5 & 11 & $4.2 \times 10^{14}$ \\
\hline
\end{tabular}

\section{Conclusions}

In this work, it was shown that, by using a diluted G. oxydans latex adhesive emulsion, ultra-thin viable $G$. oxydans coatings composed of arrays of highly reactive nanoporous latex pillars ( $<3 \mu \mathrm{m}$-thick) could be ink-jet printed onto polyester using an aspirate pipetting nano-plotter. The extremely high oxidation reactivity of these ink-jet printed microstructures exceeds that of the immobilization of $G$. oxydans in alginate beads [46]. This ink-jet micropatterning method could be used to fabricate microstructures that significantly increase the surface area available for diffusion of reactants/products to cellular biocatalysts over that of a highly ordered monolayer coating, which could be achieved by other methods, such as evaporative self-assembly of cells and particles [20]. This microbial ink and the ink-jet technique may hold considerable potential for the fabrication of ink-jet printed G. oxydans and many other types of whole cell microbial biosensors, allowing for the delivery of a high concentration of reactive microbes onto precise positions on electronic devices as adhesive, thin, nanoporous microstructures with the aim of reducing the size of biosensors to single integrated circuit chips.

In particular, in the field of Gluconobacter biosensors, there are several possible implications. For instance, co-immobilization of Gluconobacter cells with permeabilized cells containing invertase or $\beta$-galactosidase activity proposed [39] for the detection of sucrose or lactose, respectively, could be easily carried out by ink-jet printing different layers of latex inks containing the microorganisms or enzymes of interest. A general feature of microbial biosensors, including G. oxydans biosensors, is their broad substrate specificity, or low selectivity [38]. Approaches able to change G. oxydans selectivity for different substrates could make it possible to selectively analyze a mixture of substrates by using a system of differently selective G. oxydans cells. For instance, it has been shown that the ethanol-to-glucose sensitivity ratio of $G$. oxydans cells varied approximately by a ratio of three when cells were collected after 10 or $16 \mathrm{~h}$ of cultivation [52]. Thus, a set G. oxydans cells exhibiting 
different selectivity for glucose and ethanol could be easily prepared by cultivating the cells for different amounts of time. By using arrays of amperometric screen-printed sensors and ink-jet printing of G. oxydans latex inks, it could be possible to use miniaturized arrays of non-specific G. oxydans biosensors in concert to provide a selective ethanol and glucose quantification in the presence of both substrates by using chemometrics tools.

\section{Acknowledgements}

Fidaleo acknowledges the financial support of the U.S.-Italy Fulbright Commission and the North Carolina State University Golden LEAF Biomanufacturing Training and Education Center (BTEC), Raleigh, North Carolina, USA. The authors wish to thank T. Valente and F. Marra for carrying out the profilometry measurements.

\section{Conflicts of Interest}

The authors declare no conflict of interest.

\section{References}

1. Alper, J. Biology and the inkjets. Science 2004, 305, 1895.

2. Gratson, G.M.; Xu, M.; Lewis, J.A. Microperiodic structures: Direct writing of three-dimensional webs. Nature 2004, 428, doi:10.1038/428386a.

3. Li, Q.; Lewis, J.A. Nanoparticle inks for directed assembly of three-dimensional structures. Adv. Mater. 2003, 15, 1634-1641.

4. Phamduy, T.B.; Corr, D.T.; Chrisey, D.B. Bioprinting. In Encyclopedia of Industrial Biotechnology: Bioprocess, Bioseparation, and Cell Technology; Flickinger, M.C., Ed.; John Wiley \& Sons, Inc.: New York, NY, USA, 2010; Volume 2, pp. 732-741.

5. Saunders, R.; Derby, B. Bioprinting, Inkjet Deposition. In Encyclopedia of Industrial Biotechnology: Bioprocess, Bioseparation, and Cell Technology; Flickinger, M.C., Ed.; John Wiley \& Sons, Inc.: New York, NY, USA, 2010; Volume 2, pp. 741-749.

6. Flickinger, M.C.; Freeman, E.A.; Anderson, C.R.; Lyngberg, O.K.; Laudon, M.C.; Scriven, L.E. Formulation of reactive microbial latex inks for ink-jet deposition of living bacteria or yeasts. In Proceedings of the Power of Ink-Jet Materials III, Berlin, Germany, 1-2 December 2005.

7. Flickinger, M.C.; Schottel, J.L.; Bond, R.D.; Aksan, A.; Scriven, L.E. Painting and printing living bacteria: Engineering nanoporous biocatalytic coatings to preserve microbial viability and intensify reactivity. Biotechol. Prog. 2007, 23, 2-17.

8. Flickinger, M.C.; Lyngberg, O.K.; Freeman, E.A.; Anderson, C.R.; Laudon, M.C. Formulation of reactive nanostructured adhesive microbial ink-jet inks for miniature biosensors and biocatalysis. In Nanotechnology Applications in Coatings; Fernando, R.H., Sung, L.-P., Eds.; American Chemical Society: Washington, DC, USA, 2009; Volume 1008, pp. 156-187.

9. Lyngberg, O.K.; Thiagarajan, V.; Stemke, D.J.; Schottel, J.L.; Scriven, L.E.; Flickinger, M.C. A patch coating method for preparing biocatalytic films of Escherichia coli. Biotechnol. Bioeng. 1999, 62, 44-55. 
10. Lyngberg, O.K.; Stemke, D.J.; Schottel, J.L.; Flickinger, M.C. A simple single use luciferase based mercury biosensor using latex-film immobilized Escherichia coli HB101. J. Ind. Microbiol. Biotechnol. 1999, 23, 668-676.

11. Lyngberg, O.K. Development of Thin Biocatalytic Composite Coatings Consisting of Latex and Metabolically Active Bacterial Cells. Ph.D. Thesis, University of Minnesota, Minneapolis, MN, USA, 2000.

12. Lyngberg, O.K.; Ng, C.P.; Thiagarajan, V.; Scriven, L.E.; Flickinger, M.C. Engineering the microstructure and permeability of thin multilayer latex biocatalytic coatings containing $E$. coli. Biotechnol. Prog. 2001, 17, 1169-1179.

13. Lyngberg, O.K.; Solheid, C.; Charaniya, S.; Ma, Y.; Thiagarajan, V.; Scriven, L.E.; Flickinger, M.C. Permeability and reactivity of Thermatoga maritima in latex bimodal blend coatings at $80^{\circ} \mathrm{C}$ : A model high temperature biocatalytic coating. Extremophiles 2005, 9, 197-207.

14. Swope, K.L.; Flickinger, M.C. Activation and regeneration of whole cell biocatalysts: Initial and periodic induction behavior in starved Escherichia coli after immobilization in thin synthetic films. Biotechnol. Bioeng. 1996, 51, 360-370.

15. Swope, K.L.; Flickinger, M.C. The use of confocal scanning laser microscopy and other tools to characterize Escherichia coli in high-cell-density synthetic biofilms. Biotechnol. Bioeng. 1996, $52,340-356$.

16. Gosse, J.L.; Engel, B.J.; Rey, F.E.; Harwood, C.S.; Scriven, L.E.; Flickinger, M.C. Hydrogen production by photoreactive nanoporous latex coatings of nongrowing Rhodopseudomonas palustris CGA009. Biotechnol. Prog. 2007, 23, 124-130.

17. Gosse, J.L.; Engel, B.J.; Hui, J.C.; Harwood, C.S.; Flickinger, M.C. Progress toward a biomimetic leaf: $4000 \mathrm{~h}$ of hydrogen production by coating-stabilized nongrowing photosynthetic Rhodopseudomonas palustris. Biotechnol. Prog. 2010, 26, 907-918.

18. Gosse, J.L; Flickinger, M.C. Uniform lab-scale biocatalytic nanoporous latex coatings for reactive microorganisms. Methods Mol. Biol. 2011, 743, 213-222.

19. Gosse, J.L.; Chinn, M.S.; Grunden, A.M.; Bernal, O.I.; Jenkins, J.S.; Yeager, C.; Kosourov, S.; Seibert M.; Flickinger, M.C. A versatile method for preparation of hydrated microbial-latex biocatalytic coatings for gas absorption and gas evolution. J. Ind. Microbiol. Biotechnol. 2012, 39, 1269-1278.

20. Jenkins, J.; Velev, O.; Flickinger, M.C. Deposition of composite coatings from particle-particle and particle-yeast blends by convective-sedimentation assembly. J. Colloid Interface Sci. 2012, 380, 192-200.

21. Huang, Z.; Thiagarajan, V.S; Lyngberg, O.K; Scriven, L.E.; Flickinger, M.C. Microstructure evolution in polymer latex coatings for whole-cell biocatalyst application. J. Colloid Interface Sci. 1999, 215, 226-243.

22. Thiagarajan, V.S.; Huang, Z.; Scriven, L.E.; Schottel, J.L.; Flickinger, M.C. Microstructure of a biocatalytic latex coating containing Escherichia coli cells. J. Colloid Interface Sci. 1999, 215, 244-257.

23. Mota, M.; Yelshin, A.; Fidaleo, M.; Flickinger, M.C. Modelling diffusivity in porous polymeric membranes with an intermediate layer containing microbial cells. Biochem. Eng. J. 2007, 37, 285-293. 
24. Bhatti, A.; Mott, M.; Evans, J.; Edirisinghe, M. PZT pillars for 1-3 composites prepared by ink-jet printing. J. Mater. Sci. Lett. 2001, 20, 1245-1248.

25. Zhao, X.; Evans, J.; Edirisinghe, M.; Song, J. Direct ink-jet printing of vertical walls. J. Am. Ceram. Soc. 2002, 85, 2113-2115.

26. Ko, S.H.; Chung, J.; Hotz, N.; Nam, K.H.; Grigoropoulos, C.P. Metal nanoparticle direct inkjet printing for low-temperature 3D micro metal structure fabrication. J. Micromech. Microeng. 2010, 20, doi:10.1088/0960-1317/20/12/125010.

27. Kullmann, C.; Schirmer, N.C.; Lee, M.; Ko, S.H.; Hotz, N.; Grigoropoulos, C.P.; Poulikakos, D. 3D micro-structures by piezoelectric inkjet printing of gold nanofluids $J$. Micromech. Microeng. 2012, 22, doi:10.1088/0960-1317/22/5/055022.

28. Maleksaeedi, S.; Wang, J.K.; El-Hajje, A.; Harb, L.; Guneta, V.; He, Z.; Wiria, F.E.; Choong, C.; Ruys, A.J. Toward 3D printed bioactive titanium scaffolds with bimodal pore size distribution for bone ingrowth. Procedia CIRP 2013, 5, 158-163.

29. Fidaleo, M.; Charaniya, S.; Solheid, C.; Diel, U.; Laudon, M.; Ge, H; Scriven, L.E.; Flickinger, M.C. A model system for increasing the intensity of whole-cell biocatalysis: Investigation of the rate of oxidation of D-sorbitol to L-sorbose by thin bi-layer latex coatings of non-growing Gluconobacter oxydans. Biotechnol. Bioeng. 2006, 95, 446-458.

30. Fidaleo, M.; Flickinger, M.C. Engineering and modeling of thin, adhesive, microbial biocatalytic coatings for high intensity oxidations in multi-phase microchannel bioreactors. Chem. Eng. Sci. 2011, 66, 3251-3257.

31. Reshetilov, A.N.; Donova, M.V.; Dovbnya, D.V.; Il'yasov, P.V.; Boronin, A.M.; Leasers, T.; Green, R. Membrane-bound dehydrogenases of Gluconobacter oxydans: Sensors for measuring sugars, alcohols and polyoles. B. Exp. Biol. Med. 1998, 126, 702-704.

32. Deppenmeier, U.; Ehrenreich, A. Physiology of acetic acid bacteria in light of the genome sequence of Gluconobacter oxydans. J. Mol. Microbiol. Biotechnol. 2009, 16, 69-80.

33. Luong, J.H.T.; Mulchandani, A.; Groom, C.A. The development of an amperometric microbial biosensor using Acetobacter pasteurianus for lactic acid. J. Biotechnol. 1989, 10, 241-252.

34. Takayama, K.; Kurosaki, T.; Ikeda, T.J. Mediated electrocatalysis at a biocatalyst electrode based on a bacterium, Gluconobacter industrius. J. Electroanal. Chem. 1993, 356, 295-301.

35. Karube, I.; Kiyoko, Y. BOD Sensor and BOD Measuring Method. World Patent No. 95,06,242, 2 March 1995.

36. Reshetilov, A.N.; Iliasov, P.V.; Donova, M.V.; Dovbnya, D.V.; Boronin, A.M.; Leathers, T.D.; Greene, R.V. Evaluation of a Gluconobacter oxydans whole cell biosensor for amperometric detection of xylose. Biosens. Bioelectron. 1997, 12, 241-247.

37. Reshetilov, A.N.; Lobanov, A.V.; Morozova, N.O.; Gordon, S.H.; Greene, R.V.; Leathers, T.D. Detection of ethanol in a two-component glucose/ethanol mixture using a nonselective microbial sensor and a glucose enzyme electrode. Biosens. Bioelectron. 1998, 13, 787-793.

38. Lobanov, A.V.; Borisov, I.A.; Gordon, S.H.; Greene, R.V.; Leathers, T.D.; Reshetilov, A.N. Analysis of ethanol-glucose mixtures by two microbial sensors: Application of chemometrics and artificial neural networks for data processing. Biosens. Bioelectron. 2001, 16, 1001-1007.

39. Švitel, J.; Čurilla, O.; Tkáč, J. Microbial cell-based biosensor for sensing glucose, sucrose or lactose. Biotechnol. Appl. Biochem. 1998, 27, 153-158. 
40. Švitel, J.; Tkáč, J.; Voštiar, I.; Navrátil, M.; Štefuca, V.; Bučko, M.; Gemeiner, P. Gluconobacter in biosensors: Applications of whole cells and enzymes isolated from gluconobacter and acetobacter to biosensor construction. Biotechnol. Lett. 2006, 28, 2003-2010.

41. Tkáč, J.; Štefuca, V.; Gemeiner, P. Focus on Biotechnology. In Applications of Cell Immobilisation Biotechnology; Nedovič, V., Willaert, R., Eds.; Springer: Dordrecht, The Netherlands, 2005; Volume 8, pp. 549-566.

42. Fromm, J.E. Numerical calculation of the fluid dynamics of drop-on-demand jets. IBM J. Res. Dev. 1984, 28, 322-333.

43. Tekin, E.; Smith, P.J.; Schubert, U.S. Inkjet printing as a deposition and patterning tool for polymers and inorganic particles. Soft Matter 2008, 4, 703-713.

44. Friederich, A.; Binder, J.R.; Bauer, W. Rheological control of the coffee stain effect for inkjet printing of ceramics. J. Am. Ceram. Soc. 2013, 96, 2093-2099.

45. Deegan, R.D.; Bakajin, O.; Dupont, T.F.; Huber, G.; Nagel, S.R. Contact line deposits in an evaporating drop. Phys. Rev. E 2000, 62, 756-765.

46. Wang, X.; Liu, J.; Du, G.; Zhou, J.; Chen, J. Efficient production of L-sorbose from D-sorbitol by whole cell immobilization of Gluconobacter oxydans WSH-003. Biochem. Eng. J. 2013, 77, 171-176.

47. Schottel, J.L.; Orwin, P.M.; Anderson, C.R.; Flickinger, M.C. Spatial expression of a mercury-inducible green fluorescent protein within a nanoporous latex-based biosensor coating. $J$. Ind. Microbiol. Biotechnol. 2008, 35, 283-290.

48. Piskorska, M.; Soule, T.; Gosse, J.L.; Milliken, C.; Flickinger, M.C.; Smith, G.W.; Yeager, C.M. Preservation of $\mathrm{H}_{2}$ production activity in nanoporous latex coatings of Rhodopseudomonas palustris CGA009 during dry storage at ambient temperatures. Microb. Biotechnol. 2013, 6, 515-525.

49. Chini, S.F.; Amirfazli, A. Understanding pattern collapse in photolithography process due to capillary forces. Langmuir 2010, 26, 13707-13714.

50. Jenkins, J.; Flickinger, M.C.; Velev, O. Continuous convective-sedimentation assembly of colloidal microsphere coatings for biotechnology applications. Coatings 2013, 3, 26-48.

51. Zabeti, M.; Daud, W.M.A.W.; Aroua, M.K. Activity of solid catalysts for biodiesel production: A review. Fuel Process Technol. 2009, 90, 770-777.

52. Tkáč, J.; Vŏstiar, I.; Gorton, L.; Gemeiner, P.; Šturdik, E. Improved selectivity of microbial biosensor using membrane coating. Application to the analysis of ethanol during fermentation. Biosens. Bioelectron. 2003, 18, 1125-1134.

(C) 2013 by the authors; licensee MDPI, Basel, Switzerland. This article is an open access article distributed under the terms and conditions of the Creative Commons Attribution license (http://creativecommons.org/licenses/by/3.0/). 